\title{
“TREASURES” OF DEBRECEN SELECTION OF AND ATTENTION TO SPORTS TALENTS IN THE SPORT SCHOOL OF DEBRECEN
}

\author{
Danica Keczeli \\ Place of employment: Debreceni Sportcentrum - Sportiskola Nonprofit Kft.
}

\begin{abstract}
The article is about a program selecting and attending sports talents in order to select and attend to the conscious sports talents so as to support convenient supply for the sections of the Sport School of Debrecen as well as for the adult sports organizations of Debrecen.
\end{abstract}

Key words: Sport, selecting talents, attention, choosing branch of sport

\section{Introduction}

\begin{abstract}
"Sport is not only physical training but one of the most powerful tools of educating the soul. Sport opens our mind through our body."
\end{abstract}

Albert Szent-Györgyi

There is an apparent and exciting tendency, that appears in sport. More and more countries and sportsmen take part in the Olympic Games. Moreover, during the past years achievements in sports have progressively increased. So considering the leading international results, it is obvious that only youths with prominent, peculiar faculties can be prepared (Harsányi, 2000).

Nowadays it is not an easy thing at all to decide what sport the child should choose. It is a difficult question for parents to know if they chose the right sport to their child according to his conditions. Or are there any possibilities to direct a child to the best kind of sport for him before starting any branches of sport?

It is well known that achieving a record is possible only with the sportsman of best faculties, but obviously the quality and the quantity of training are decisive factors as well. Today's sport racing, international results require the continuous and objective measuring of sportsmen to help the process of selection and proving to be suitable of sportsmen (Révész- Géczi- Bognár-Tóth, 2005/4).

On the other hand, sport racing has to face more and more competitors just like television, computer, malls besides studying, furthermore in nowadays' educational systems PE is pushed into the background. Because of faster life, changed value systems former methods of selection are not effective enough.

Kincskereső program was called into life exactly because of this situation. According to the problems mentioned above we decided to select the ones with special, peculiar faculties and we initiate them into the planned, systematic training. There are many possibilities for parents and children to chose from the many-sided trainings, branch of sport specific trainings. The program gives an opportunity to the selected youths and to their parents to get acquainted with all the branches of sport of the sport school and then to decide with the help of the experts of the sport school - which branch of sport stands closer to them in which they feel that they can be successful.

\section{The theory of sports talent}

According to Frenkl (2003) sports achievement is a human achievement refers to man as a biosocial being. The most accepted theory of talents in sports racing was created by Mönks and Knoers (1997). The multi-factor model emphasizes commitment for work, creativity and capacities above the average, contemporaneously these factors are influenced by the family, school and friends (Figure 1.). According to these Mönks (1997) said that talent comes from the interaction of the three terms of personality. For healthy development tolerant, supporting social background is needed from the side of the family, school and friends. In other words the interaction of the six terms causes the appearance of talent (Mönks-Boxtel, 2000).

On the basis of their researches they came to the conclusion that there are primary and secondary influential factors of sports talent. Primary effective factors: genetic, psychological factor and the process of training itself, while secondary effective factors: socio-cultural factors and conditions in connection with the context of the branch of sport.

Two basic categories are accepted in defining sports talent: in one of the categories the general talents are placed, 


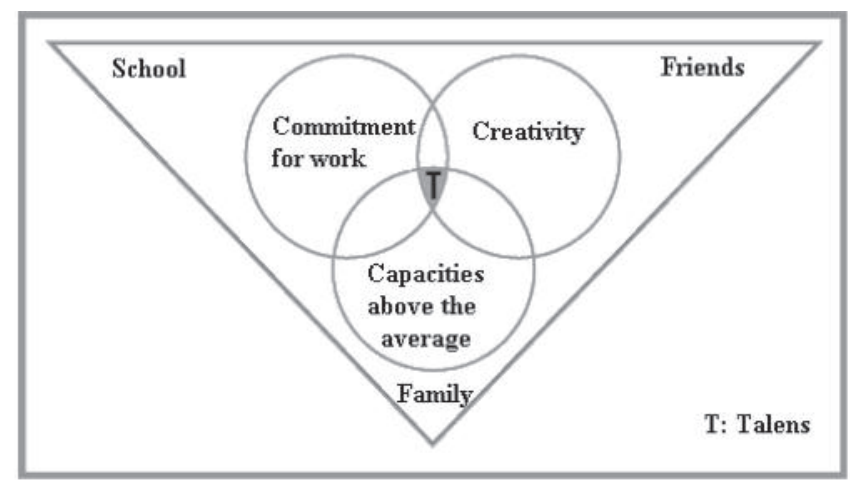

Figure 1. The multi-factor model of Mönks and Knoers (1997)

while in the other category there are the special talents. Sports activity is placed to the second category because all the sports activities take places in special surroundings, situations with special conditions (Harsányi, 2000).

\subsection{Subject, definition and tasks of the sports talent theory}

Sports talent is a person, whose state of health, mental, physiological, anthropometrical, motor and socialisational faculties - in a period of his development - are on a level and are developing in a rate during the periods of preparing, which - near convenient training and other, mostly social surroundings - possibly in his maximum output age lead to reaching high-level achievements in a branch of sports or on a sports event.

There are two big groups of the factors that influence sports achievements in interaction with each other:

- direct achievement-determining factors: level of conditional, movement-technical and tactical abilities and faculties

- indirect achievement-determining factors: physique, organ systems, functional level of informative and executive systems.

So sports talent theory deals with youths who have the characteristics mentioned above in their early ages. These achievement-determining factors are the results of partially heredity and partially the influences of the milieu.

Tasks of sports talent theory:

- measurement of hereditary facilities,

- measurement of the influences of the milieu,

- conformance of personality and branch of sport,

- organizational tasks,

- working out of tools and methods (Harsányi, 2000).

\subsection{Choosing branch of sport, selection}

One of the main aims of recognition and selection of talents is to recognize marks relating to talent and to train them satisfactorily (Herskovits, 2005). That's the main motto of Kincskeresö program. The characteristics of the selection for leading sports had been examined since 1950's (Harsányi-Sebö, 1989). The aspects of selection are different and specific in every branch of sport, they contain physical characteristics, motor achievements, motion-learning and important mental and cognitive factors according to the branch of sport (Baumgartner-Bognár-Géczi, 2005).

The number of the choosers of a branch of sport and their motivation in choosing that branch of sport determine the success of selection. According to Gál's study (2003) more than the half of the asked students chose the given branch of sport because they wanted to reach a selected level or first class classification. It is an interesting fact that one third of the asked ones says that they started sporting as a hobby or pleasure to spend their free time.

With the development of technique and science the methods and procedures of selection have changed as well. The significant methods of selection can be put into four groups: (1) natural selection, (2) indirect selection, (3) selection based on success and (4) scientific selection. Nowadays first of all scientific selection is the fundamental type of selection (Harsányi-Sebö, 1989).

According to the opinion of Rókusfalvy (1986) it is obviously not enough for any branches of sport to have certain physical and antropometrical faculties, mental suitability to the characteristics of the chosen branch of sport is also needed. Relying upon these findings that can be told that complex examination is an essential requirement of modern selection, that measures social, physical, mental a biological conditions, faculties with pedagogical methods.

\section{Kincskereső program}

The target group of selection and attention: $3^{\text {rd }}$ class (8-9 years old). This selection is based on mixture of the natural and the scientific selection.

\subsection{The structure of Kincskeresö program}

The process of "treasure hunt"1 has three parts:

1. Visiting elementary schools. Selecting sports talents, indentifying the talent.

2. Examining those kids, who appears to be talented. (examination of health suitability by a sports doctor, gauging physical faculties, psychological examination if necessary)

3. Development and attention of sports talents. This part has two more parts:

a. The many-sided training

b. The branch of sport specific trainings.

After eight months of both of the two types of the trainings our "treasures" choose a branch of sport and are transferred to the chosen section where their training continues.

During the development of sports talent over and above the development of special faculties, we try to develop general, basic faculties as well, in case the kid wants to change to another branch of sport.

\footnotetext{
${ }^{1}$ Treasure hunt in Hungarian is the name of the program: Kincskeresés
} 


\subsection{The realization of the program: - Information of schools}

Before the process of selection some preparations always take place. We inform the principals, physical trainers, teachers of the elementary schools of Debrecen on a personal meeting about the program, its changes, so they get information about all the details of "treasure hunt". During the meeting we collect all the necessary information for the selection about the kids.

\section{Necessary preparations for starting the selection:}

- To find out the number of schools, that want to take part in the program. The students of the given classes get into the computerized database of the Sport School of Debrecen based on the data sheets made by their teachers.

- To establish contact with the principles, physical trainers, teachers.

- To fix the date of the first surveys.

Only after these preparations can the process of selection be started in the sport school.

\section{- The three parts of selection:}

1. According to the preliminary visit of the school and the applying to the program - we ask the opinion of the physical trainer about the students. During the first surveys in the schools we check the kids' motion and fighting faculties.

Selection is based on the actually reached results and personal experiences. We inform in a letter the parents of those kids who are qualified for the next round.

Considered points in the course of selection:

- good motion coordination,

- good physique,

- fastness, strength, staying power,

- fighting spirit, attitude,

- opinion, suggestion of the teacher.

2. The selected kids with their parents get into the Sport School. Here we talk to either the kids or their parents and we give them every necessary information. Then new surveys, examinations start, with the following parts:

- testing physical faculties,

- suitability examination by a sports doctor.

Considering the results we put the kids into groups (mixed groups, maximum 22 kids in each group).

3. This part does not contains only the selection of talents but their training, as well. A developing work takes place while the talents are selected by their own exercises, trainings.

It has two main parts:

a. the many-sided training, where fastness, staying power, capacity, power are developed, and

b. the branch of sport specific trainings, where coaches of our school introduces the branches of sport for students.
These are: athletics, judo, handball (for boys, for girls), football, badminton, ice-skate, swimming.

This third part is based on our own requirement system. Partially we imitate the "Finnish-model", so our goal is to ensure optimal development of faculties in every group, this is why we get approximately the same quality and intensity of work in every group.

Besides our students get experiences in our branches of sports, two other significant things are in the selection of the branch of sport: we take them under sports psychological examinations and we measure their tolerance of monotony. After these the sports anthropometrical exam takes place where we can estimate the physique and height of the adulthood considering the 24 physical parameters. Finally on the basis of all this we make a proposal for the branch of sport.

\section{Results}

Kincskereső program was established in order to make it possible to us to chose kids from a wide circle. Our goal was to make the selection of talents conscious. From the 38 schools of Debrecen we asked 32 to cooperate with us. On Table 1. it is visible that the popularity and acceptance of the program increased year by year.

Table 1. Schools of Kincskereső program

\begin{tabular}{|l|c|c|c|c|}
\hline $\begin{array}{l}\text { school } \\
\text { year }\end{array}$ & $\begin{array}{c}\text { number } \\
\text { of schools } \\
\text { participating } \\
\text { in the program- }\end{array}$ & $\begin{array}{c}\text { number } \\
\text { of } 3^{\text {rd }} \\
\text { classes }\end{array}$ & $\begin{array}{c}\text { number of } \\
\text { kids }\end{array}$ & $\begin{array}{c}\text { "Treasures" } \\
\text { put in } \\
\text { Sport } \\
\text { School }\end{array}$ \\
\hline $2007 / 2008$ & 23 & 55 & 1252 & 120 \\
\hline $2008 / 2009$ & 28 & 60 & 1405 & 98 \\
\hline $2009 / 2010$ & 29 & 59 & 1403 & Oct. 2010. \\
\hline
\end{tabular}

The successful past three years of the program shows that kids and parents need help in selecting a branch of sport.

We made a questionnaire to make a research among those parents, whose kids already pursue a branch of sport, and we get the following results:

- the program is attractive mostly because in the Sport School kids can try many branches of sport in the presence of coaches, physical trainers;

- kids and their parents get known the branch of sport and its coach as well during the program;

- kids and their parents like the swimming camp, where near swimming and other sports, there are many conversations, new friends;

- there are more point of views of the selection of a branch of sport: kid's interest in something, popularity of the branch of sport, personality of the coach, results of the anthropometrical examination;

- regular sports and the time spent with it have no negative effects on the student's school results.

When we talk about conscious, scientific selection of sports talent, it is necessary to mention sports anthropometrical examinations. During this examination we take 24 
physical data and based on these data we can calculate the weight $(\mathrm{kg})$ in an absolute value of the muscle, the bone, the fat and the residuum (internal organs), moreover the relative rate $(\%)$ of each physical components compared to the weight can be calculated. According to the constitution and the estimated weight of bones we can define the person's strengthening capacity. The expectable height can be estimated punctually with $\pm 2 \mathrm{~cm}$.

We assume that kids and their parents will choose a branch of sport with the help of the coaches, trainers, examinations. There are many factors that participate in the selection of the branch of sport, in the first place there is the characteristic of the branch of sport, interest in the branch of sport, and the popularity of the branch of sport. Then comes the personality of the coach.

The development of sports talents takes place in mixed groups. Originally we wanted to make the groups according to the results of the members but it failed because parents preferred other factors, such as friends, schoolmates - so we based the groups on the model of Mönks.

\section{Conclusion}

The success of our program proves that in today's Hungary needs a global system selecting and training sports talents. Sport has a social and cultural and economical significance. According to some researches, nowadays $20 \%$ of the Hungarian population do sports regularly every week. This spells serious danger. The lack of sports is because of the lack of possibilities and the lack of purpose. This is what we want to change. This is a complex process. First of all a financial background is needed to support the employment of couches, use of sports tools. On the other hand the part of the parents in this process is very important as well, just like the ideals, successful sportsmen, teams are needed as examples to kids.
Our main aim is to train young sports talents but to continue their training in their adulthood as well, and to develop internationally successful sportsmen in Debrecen for the society of Hungary.

\section{References}

Baumgartner E. - Bognár J. - Géczi G. (2005): A tehetség fogalmának értelmezése: testnevelés szakos hallgatók álláspontja. $I V$. Országos Sporttudományi Kongresszus Tanulmánykötet II. 35-38.

BAKER, J. - HORTON, S. (2004): A review of primary and secondary influences on sport expertise. High ability studies, 15, 2, 211-228.

CZEIZEL E. (2004): Sors és tehetség. Urbis Könyvkiadó, Budapest. ISBN 9639291609

FRENKL R. (2003): Sporttehetség. Magyar Sporttudományi Szemle, 2. sz. 16

GÁL L. (2003): A sport iránti érdeklődés és a sportágválasztás indítékai szombathelyi tanulók körében. IV. Országos Sporttudományi Kongresszus Tanulmánykötet II. 110-116

Harsányi L. (2000): Edzéstudomány I. Dialóg Campus Kiadó, Budapest - Pécs. ISBN 9639123374 ö

Herskovits M. (2005): Mit kezdjünk a tehetséggel? Iskolakultúra, 4. sz. 25-36.

Harsányi L. - Sebő A. (1989): Módszer a kiválasztás és válogatás értékelésére. Atlétika, 5. sz. 3-7

Lénárt Á. (szerk.) (2002): Téthelyzetben. Sportpszichológiáról edzőknek és versenyzőknek. Sportkórházi sorozat, OSEI, Budapest. ISBN 9632061764

Mönks, F. J. - Knoers, A. M. P. (1997): Ontwikkelingpsychologie. $7^{\text {th }}$ ed. Assen, Van Gorcum.

NÁDORI L. (1980): Az edzés és a versenyzés pszichológiája. Sport Kiadó, Budapest. ISBN 9632533623

Révész L. - Géczi G. - Bognár J. - Tóth L. (2005): A sporttehetség megközelítési módja Magyar edzö 4. 5-8.

ROKUSFALVY P. (1986): A sport és testnevelés pszichológiája. Sport Kiadó, Budapest. J 1319.

http://www.citatum.hu/szerzo/Szent-Gy\%F6rgyi Albert 